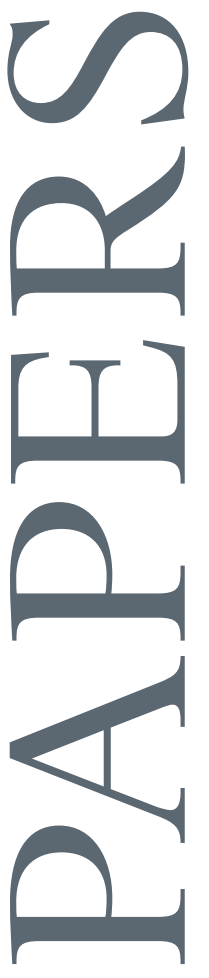

EAST-WEST CENTER WORKING PAPERS

Innovation and Economic Growth Series

No. 6, March 2016

From Catching Up to

Forging Ahead in Advanced Manufacturing-Reflections on China's Future of Jobs

Dieter Ernst

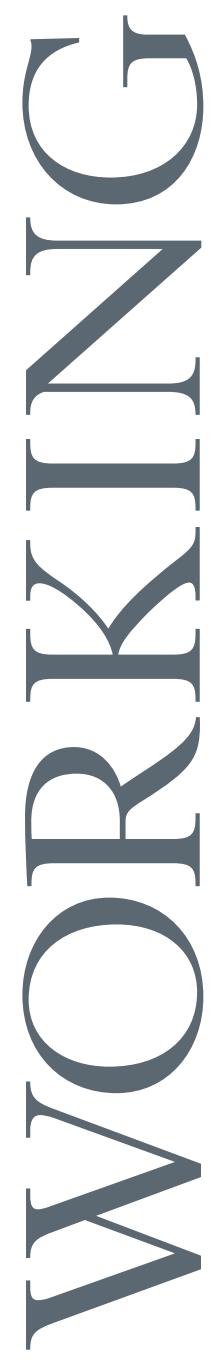

드 $\frac{\text { E A S T - W E S T C E N T E R }}{\text { Collaboration - expertise. Leadership }}$ 


\title{
From Catching Up to Forging Ahead in Advanced Manufacturing-Reflections on China's Future of Jobs
}

\author{
Dieter Ernst
}

East-West Center Working Papers is an unreviewed and unedited prepublication series reporting on research in progress. The views expressed are those of the author and not necessarily those of the Center. East-West Center Working Papers are circulated for comment and to inform interested colleagues about work in progress at the Center.

Working Papers are available online for free at

EastWestCenter.org/ewcworkingpapers.

The East-West Center promotes better relations and understanding among the people and nations of the United States, Asia, and the Pacific through cooperative study, research, and dialogue. Established by the US Congress in 1960, the Center serves as a resource for information and analysis on critical issues of common concern, bringing people together to exchange views, build expertise, and develop policy options.

The Center's 21-acre Honolulu campus, adjacent to the University of Hawai'i at Mānoa, is located midway between Asia and the US mainland and features research, residential, and international conference facilities. The Center's Washington, DC, office focuses on preparing the United States for an era of growing Asia Pacific prominence.

The Center is an independent, public, nonprofit organization with funding from the US government, and additional support provided by private agencies, individuals, foundations, corporations, and governments in the region.

\section{EastWestCenter.org/publications}

Publications Office| East-West Center 1601 East-West Road | Honolulu, Hawai'i 96848-1601

Tel: 808.944.7145 | Fax: 808.944.7376

EWCBooks@EastWestCenter.org
Dieter Ernst, an East-West Center senior fellow, is an authority on global production networks and the internationalization of research and development in high-tech industries, with a focus on standards and intellectual property rights. His research examines corporate innovation strategies and innovation policies in the United States and in China, India, Taiwan, Korea, Malaysia, and other emerging economies. The author has provided testimony to the US Congress, and has served as a member of the United States National Academies "Committee on Global Approaches to Advanced Computing"; senior advisor to the Organisation for Economic Co-operation and Development, Paris; research director of the Berkeley Roundtable on the International Economy at the University of California at Berkeley; professor of international business at the Copenhagen Business School; and scientific advisor to governments, private companies, and international institutions.

Paper prepared for the conference at Mount Holyoke College on The Future of Jobs: The Dual Challenges of Globalization and Robotization, February 19-20, 2016. 


\title{
From Catching Up to Forging Ahead in Advanced Manufacturing- Reflections on China's Future of Jobs ${ }^{1}$
}

by

\author{
Dieter Ernst \\ East-West Center, Honolulu
}

\begin{abstract}
This paper explores what we know about possible employment effects of the 10-year plan, issued by the State Council on May 19, 2015, entitled Made in China 2025. MIC2025 was designed to address China's emerging labor shortage challenge. To achieve this goal, the plan seeks to boost labor productivity through an increased use of robots and through network-based upgrading of the entire industrial value chain and related services.
\end{abstract}

How might the projected increase in labor productivity affect the creation and quality of jobs in China? Will China's push into advanced manufacturing now move the country's manufacturing employment closer to the pattern of "employment de-industrialization" observed in the US and other industrialized countries?

How China will cope with the advanced manufacturing challenge for employment will have major implications not only for the US and other industrialized countries, but also for emerging economies and, most importantly for the majority of developing countries that are still struggling as latecomers to labor-intensive industrial manufacturing. The paper lays out objectives of the MIC 2025 plan and highlights a failure of Chinese policy makers to take into account employment effects and other labor market issues when they design their grand visions of industrial policy.

The paper finds that until 2014, manufacturing has acted as an employment absorber in China. However new data on unemployment, labor force participation and income inequality signal that China may now be moving towards an "employment de-industrialization" pattern, unless enough knowledge-intensive service jobs will be created in China's growing information economy. The paper concludes with implications for policy and further research.

\footnotetext{
About the author

Dieter Ernst, an East-West Center senior fellow, is an authority on global production networks and the internationalization of research and development in high-tech industries, with a focus on standards and intellectual property rights. His research examines corporate innovation strategies and innovation policies in the United States and in China, India, Taiwan, Korea, Malaysia, and other emerging economies. The author has provided testimony to the US Congress, and has served as a member of the United States National Academies "Committee on Global Approaches to Advanced Computing”; senior advisor to the Organisation for Economic Co-operation and Development, Paris; research director of the Berkeley Roundtable on the International Economy at the University of California at Berkeley; professor of international business at the Copenhagen Business School; and scientific advisor to governments, private companies, and international institutions.
} 


\section{China's Advanced Manufacturing Challenge}

China has reached a level of development where catching up through an investment-driven "Global Factory" model is no longer sufficient to create long-term economic growth and prosperity. Serious constraints on environmental, human and financial resources imply that economic growth based on scale expansion is running out of steam. The closer China has moved to the technology frontier, the less scope there is for imitation and low-level incremental innovation. Of critical importance now is that Chinese firms develop and protect their own intellectual property rights and accelerate the commercialization of new ideas, discoveries, and science-based industrial inventions.

Since the Third Plenum, China's leadership has emphasized the need to upgrade the manufacturing industry beyond catching-up with global industry leaders to forging ahead in advanced manufacturing ${ }^{2}$. Emblematic of the shift to an innovation-driven development model are a series of policy initiatives that seek to accelerate major changes in China's industrial strategy and its innovation system.

This Think Piece focuses on possible employment effects of one such policy initiative, the 10year plan, issued by the State Council on May 19,2015, entitled "Made in China 2025 MIC2025" "中国制造2025" ${ }^{3}$. As MIC 2025 has not yet moved beyond the "vision stage”, it would be premature to search for definite answers or solutions. The purpose instead is to get a conversation started on a set of questions that this plan might raise for the future of jobs in China. As for the reader, some patience will be required to digest a few definitions of key concepts and some illustrative data points and case examples.

In essence, MIC 2025 reflects the leaderships' concern that China's industry needs to upgrade beyond low-value added segments of the supply chain in order to compensate for the loss in labor cost advantages and a declining working population. Since the turn of the century, China has been experiencing a nationwide labor shortage and steep rises in worker wages, including for immigrant workers ${ }^{4}$. Development economists call this the "Lewis turning point" (named after nobel laureate economist W. Arthur Lewis - a term that is used to describe a point or rather a period during which "the rural wages begin to converge with the industrial sector. At that point, labour shortages appear and urban employers must offer higher wages to lure workers from the countryside. Corporate profits, export competitiveness and asset prices fall.." ${ }^{5}$

MIC2025 was designed to address this emerging labor shortage challenge. To achieve this goal, MIC 2025 seeks to boost labor productivity through an increased use of robots and through network-based upgrading of the entire industrial value chain and related services. A $7.5 \%$ annual growth of labor productivity is projected until 2020, and from then on an annual 6.5\% productivity growth. This would require a reversal of China's long-term productivity slow-down from almost 9.5\% during 2007-2012 to an estimated 6.7\% for $2015^{6}$.

How might the projected increase in labor productivity affect the creation and quality of jobs in China? This country today is the largest global manufacturing site and the largest exporter of manufactured products. But will China's push into advanced manufacturing now move the country's manufacturing employment closer to the pattern of "employment de-industrialization" observed in the US and other industrialized countries? According to Lawrence and Edwards, US 
manufacturing employment has grown more slowly than employment in the overall economy, due to a "combination of productivity growth, demand for goods, and international trade"7 . Will China face a similar experience?

It is necessary to add an important caveat. For analytical clarity, this paper focuses on a limited set of possible determinants of employment generation, i.e. the combined effect of technical change and a country's industrial development strategy, as embodied for instance in the MIC 2025 plan. In my view, a narrow focus on robot-based automation alone is insufficient to get to the root causes ${ }^{8}$. Potential employment effects of technical change are obviously shaped by broader determinants of a country's production and innovation system, such as the stage of development, the growth model and regulations, and the available resources and capabilities. Potential employment effects might as well be constrained by misaligned incentives and poor governance, distorted allocation of resources and capital, as well as by impediments to the supply of skills and access to knowledge.

There is a rich body of work that examines these parameters of China's current industrial upgrading efforts ${ }^{9}$. This paper will not repeat those findings. It focuses instead on the following three questions: Is China, this role model of Latecomer Industrialization, now facing a slowdown in manufacturing employment due to the combined forces of technical change (e.g. robotics, networked intelligent manufacturing or 3D printing) and an industrial strategy which seeks to combine domestic capability development with a deep integration into international trade and FDI through global networks of production and innovation? Alternatively, might China now become trapped in a pattern of "premature deindustrialization” typical for developing countries, where manufacturing begins "to shrink (or is on course for shrinking) at levels of income that are a fraction of those at which the advanced economies started to deindustrialize" ${ }^{20}$ ? Or, thirdly, will China find ways to avoid those two destructive "Future of Jobs" scenarios, and what role (if any) might industrial policies like MIC 2025 play?

As China now is the second largest player in the global economy, we all need to understand what really happens to China's manufacturing employment. How China will cope with the advanced manufacturing challenge for employment will have major implications not only for the US and other industrialized countries, but also for emerging economies and, most importantly for the majority of developing countries that are still struggling as latecomers to labor-intensive industrial manufacturing.

Part One of the paper lays out objectives and important features of the "Made in China 2025" plan. Part Two highlights possible implementation constraints, such as a bias for a rapid expansion of tangible infrastructure and equipment while capabilities in advanced manufacturing technologies remain weak. Arguably one of the most problematic weaknesses of MIC 2025 is a failure of Chinese policy makers to take into account employment effects and other labor market issues when they design their grand visions of industrial policy.

Part Three asks what we know or don't know about China's manufacturing employment. Thus far China does not seem to have followed the "employment de-industrialization" observed in the US, nor do the available data indicate that China is likely to be caught in the trap of "premature deindustrialization”. But as MIC 2025 fails to provide robust employment projections, we know 
very little about China's future of jobs now that China's growth is slowing and as the new push into advanced manufacturing gets off the ground. However new data on unemployment and labor force participation raises the question whether China may now be moving towards an "employment de-industrialization" pattern. Or have enough knowledge-intensive service jobs been created in China's growing information economy which is the necessary foundation of forging ahead in advanced manufacturing?

\section{The paper concludes with implications for policy and further research.}

\section{Part One - The “Made in China 2025” Plan}

MIC 2025, a ten-year plan to upgrade China's industry through flexible automation and computer-based network integration, was drafted by the Ministry of Industry and Information Technology (MIIT) over two and a half years, with input from 50 experts from the China Academy of Engineering and the Chinese Academy of Sciences, as well as around 100 experts from industry and research institutes. Issued by the State Council on May 19, 2015, MIC 2025 has the full support of China's leadership - Vice Premier MA Kai heads the Leading Small Group that is responsible for effective implementation.

In contrast to earlier plans, like the Medium- and Long-Term Plan for Science and Technology Development (MLP) of 2006, and the Strategic Emerging Industries (SEI) plan of $2012^{11}$, MIC 2025 moves beyond science and technology and seeks to upgrade all stages of China's industrial supply and demand chains.

The plan is a direct response to Germany's "Industrie 4.0" initiative that seeks to integrate factories, research labs, and service providers across domestic and global supply chains through flexible automation and the Internet of Things in industrial manufacturing ${ }^{12}$. The design of MIC 2025 also draws on other international benchmarks that pursue similar advanced manufacturing upgrading strategies ${ }^{13}$.

Germany has the advanced technology needed for MIC 2025, and thus is China's preferred partner. For the German government and its leading corporations, demand from China offers unique sales opportunities. ${ }^{14}$. For Germany's innovative SMEs however, protection of intellectual property rights and data security are major unresolved issues. ${ }^{15}$ It remains unclear what lasting benefits China might be able to capture.

The challenge for China's industry is that it is still in transition from Industry 2.0, which is mainly assembly lines, to Industry 3.0, which uses more industrial automation, electronics and IT. Today, only about $60 \%$ of Chinese companies use industrial automation software, such as Enterprise Resource Planning (ERP). And the internet adoption ratio of Chinese SMEs reaches only $25 \%{ }^{16}$. To reduce this huge gap, MIC 2025 encompasses upgrading objectives for processes, R\&D, human capital development, intellectual property rights, as well as technical standards.

In essence, MIC 2025 addresses the following over-riding objectives: a big push in firm-level industrial innovation capacity (focused on R\&D and patents); quality improvement and accelerated productivity growth and quality; an expansion of informatization and digitization of 
industry; and "green development", focusing on a reduction of energy consumption, water usage and pollution. ${ }^{17}$

In order to implement these objectives, MIC 2025 seeks to provide a new framework for coordinating industrial support policies to overcome a persistent gap in technological, management and innovation capabilities across the whole gamut of China's manufacturing industry. Improved policy coordination is considered to be particularly important in order to reduce the fragmentation of decision-making across government agencies and between the Central government and local governments. There is a broad consensus that improved coordination is essential for overcoming deeply entrenched disconnects between industry, academia and government. As an important step in this direction, MIIT has brought14 state-run associations from different sectors together and created a voluntary quality management standard for automated and intelligent manufacturing.

MIC 2025 highlights 10 priority sectors for China’s push into advanced manufacturing: 1) New advanced information technology; 2) Automated machine tools \& robotics; 3) Aerospace and aeronautical equipment; 4) Maritime equipment and high-tech shipping; 5) Modern rail transport equipment; 6) New-energy vehicles and equipment; 7) Power equipment; 8) Agricultural equipment; 9) New materials; and 10) Biopharma and advanced medical products.

For each of these priority areas, MIC 2025 provides objectives, albeit still on a quite general level. For instance, for New advanced information technology, the plan sets out the following priorities: i) Catch up with world best practice in IC design cores and design tools; ii) move to the frontier of multicomponent semiconductors (MCOs); iii) win design-in contracts from Chinabased electronic equipment manufacturers (both large global MNCs and Chinese firms like Lenovo or Huawei); and iv) strengthen China's capacity to design and produce high-density chip packages and 3D micro-package technology. These specific priorities are practically identical with the objectives of China's strategy to upgrade its semiconductor industry (as outlined in the in the Guidelines to Promote National Integrated Circuit Industry Development, June 24, $2014^{18}$ ). At least for this particular priority sector, this raises the question whether MIC $2025 \mathrm{si}$ just repackaging under a different name already well publicized existing policy initiatives ${ }^{19}$.

A fundamental assumption underlying MIC 2025 is that forging ahead in advanced information technology is necessary for realizing in particular the following pet projects of China's leadership: Develop production \& innovation capabilities for large aircraft and aircraft engines; internal combustion turbines; intelligent green trains; e-cars; marine engineering equipment; high-tech ships; smart grid equipment; high-end NC machine tools; nuclear power equipment; high-end medical equipment.

\section{Part Two - Implementation Constraints - Barking at the Wrong Tree?}

Some observers argue that the strategy and the implementation policies of MIC2025 may fail to address China's real industrial upgrading problems. As this plan closely follows Germany's Industrie 4.0 initiative, there may be an insufficient understanding of how Germany's situation differs from that faced by China’s industry. 
Germany still has a very sound industrial base, especially in the SME sector, and there is little concern in Germany that Industrie 4.0 will lead to "employment de-industrialization". In essence, Industrie 4.0 seeks to upgrade Germany's current advantage in mechanical engineering and the chemicals industry through pervasive network-based upgrading of the entire value chain and related services. The idea is to leap ahead with mass customization of production - "for each consumer his own personally designed device”.

By contrast, much of China's industry is still stuck in very basic manufacturing - and many of these factories will not survive the next 10 years without major upgrading of facilities and production processes. The table below indicates that China's industrial technological capacity continues to lag well behind comparator countries - it has the lowest percentage share of R\&D in GDP, the highest energy consumption, and it faces substantially higher quality problems in its exports. Of particular concern are weak capabilities in high-end molds and dies, i.e. the press metal molds used in automotive outer body panels and for precision motor cores, and all-in-one printer cartridge molds. For those high-end molds and dies, China continues to depend on imports from Japan and Germany ${ }^{20}$

\begin{tabular}{|c|c|c|c|}
\hline \multicolumn{4}{|c|}{$\begin{array}{l}\text { Technology capabilities in Manufa } \\
\text { US, Germany, Japan, Korea (2012) }\end{array}$} \\
\hline $\begin{array}{l}\text { Indicatorl } \\
\text { Country }\end{array}$ & $\begin{array}{l}\text { \% of R } 8 D \\
\text { in GDP }\end{array}$ & $\begin{array}{l}\text { Mfg indy } \\
\text { energy } \\
\text { consumption } \\
\text { per unit of GDP }\end{array}$ & $\begin{array}{l}\text { Index of recall } \\
\text { notices for } \\
\text { exported } \\
\text { products }\end{array}$ \\
\hline China & 1.60 & 0.26 & 0.285 \\
\hline US & 2.85 & 0.16 & 0.043 \\
\hline Germany & 2.87 & 0.11 & 0.038 \\
\hline Japan & 3.48 & 0.11 & 0.023 \\
\hline Korea & 3.45 & 0.18 & 0.027 \\
\hline
\end{tabular}

All of this raises the question how useful MIC2025 can be as long as it is largely modeled on industrial upgrading strategies like Germany’s Industrie 4.0 or the US Advanced Manufacturing Partnership (AMP). But can these foreign strategies work under the quite different conditions of China's industry?

\section{i) Robots are all the rage, but installation is growing from a low base}

Robots and in particular flexible and autonomous robots are supposed to play an important role in the MIC 2015 plan. Let us look at China's official data on the use and local production of robots, and on the progress made towards autonomous robots ${ }^{21}$. From 2009 to 2014, sales of industrial robots in China increased by an annual average of 59\%. In 2014, sales volume reached about 57,000 units, which amounted to about one fourth of the total global robot sales. 
For 2014, CRIA reports that 29 manufacturing sectors in China were using robots (up from 26 in 2013). For 2015, the growth of robot sales is estimated at 25\%, with the growth rate of the domestic robot suppliers' sales estimated at over $40 \%$.

As the table 2 below shows, China has rapidly caught up with the global leaders in terms of the operational stock of multipurpose industrial robots. The media have widely reported on prestige projects, like the Swiss ABB robot project (the largest industrial robot R\&D and production base in the southern part of China in Zhuhai High-tech Zone), and the all-robot manufacturing plant in Dongguan. ${ }^{22}$ According to industry observers, many factories in the Pearl River Delta, the heart of China's world factory, are investing in robots, as labor shortages bite and local authorities face the need to spur innovation to counter the economic slowdown. ${ }^{23}$

Table 2

\section{Estimated operational stock of multipurpose industrial robots at year-end in selected} countries. Number of units

\begin{tabular}{|c|c|c|c|c|}
\hline Country & 2013 & 2014 & $2015^{\star}$ & $2018^{\star}$ \\
\hline America & 226,071 & 248,430 & 272,000 & 343,000 \\
\hline Brazil & 8,564 & 9,557 & 10,300 & 18,300 \\
\hline North America (Canada, Mexico, USA) & 215,817 & 236,891 & 259,200 & 323,000 \\
\hline Other America & 1,690 & 1,982 & 2,500 & 1,700 \\
\hline Asia/Australia & 689,349 & 785,028 & 914,000 & $1,417,000$ \\
\hline China & 132,784 & 189,358 & 262,900 & 614,200 \\
\hline India & 9,677 & 11,760 & 14,300 & 27,100 \\
\hline Japan & 304,001 & 295,829 & 297,200 & 291,800 \\
\hline Republic of Korea & 156,110 & 176,833 & 201,200 & 279,000 \\
\hline Taiwan & 37,252 & 43,484 & 50,500 & 67.000 \\
\hline Thailand & 20,337 & 23,893 & 27,900 & 41,600 \\
\hline other Asia/Australia & 29,188 & 43,871 & 60,000 & 96,300 \\
\hline Europe & 392,227 & 411,062 & 433,000 & 519,000 \\
\hline Czech Rep. & 8,097 & 9,543 & 11,000 & 18,200 \\
\hline France & 32,301 & 32,233 & 32,300 & 33,700 \\
\hline Germany & 167,579 & 175,768 & 183,700 & 216,800 \\
\hline Italy & 59,078 & 59,823 & 61,200 & 67,000 \\
\hline Spain & 28,091 & 27,983 & 28,700 & 29,500 \\
\hline United Kingdom & 15,591 & 16,935 & 18,200 & 23,800 \\
\hline other Europe & 81,490 & 88,777 & 97,900 & 130,000 \\
\hline Africa & 3,501 & 3,874 & 4,500 & 6,500 \\
\hline not specified by countries ${ }^{* *}$ & 21,070 & 32,384 & 40,500 & 41,500 \\
\hline Total & $1,332,218$ & $1,480,778$ & $1,664,000$ & $2,327,000$ \\
\hline
\end{tabular}

However, China continues to lag behind in the use of industrial robots: While in Germany 282 industrial robots are installed per 10,000 factory workers, that ratio is much lower for China: 14 industrial robots per 10,000 factory workers ${ }^{24}$. On the supply side, China remains heavily dependent on foreign technology: 75\% of all robots used in China are purchased from foreign firms (some with assembly lines in China), and China remains heavily dependent on imports of costly core components from Japan. 
The latest count of local robot production reports 107 Chinese companies, but many of them produce robots with low quality, safety and design standards. According to industry experts, less than 50 of those companies are likely to survive. And even these companies, including industry leaders like SIASUN Robot\&Automation Co.Ltd ${ }^{25}$, are struggling with excess capacity and the lack of a vibrant local core components industry. More fundamentally, worker flexibility remains crucial for Chinese manufacturing industries, which constrains demand for robots ${ }^{26}$.

\section{ii) Weak innovation capacity for advanced manufacturing technologies}

Another important stumbling block for implementing MIC2025 may well be a persistent gap in China's industrial innovation capacity for advanced manufacturing technologies. A recent Fraunhofer Institute study finds that Chinese researchers have patented important inventions in key advanced manufacturing technologies, including wireless sensor networks, embedded systems, low-cost robots and big data ${ }^{27}$. In terms of the number of patents filed for industry 4.0 technologies, the Fraunhofer study finds that China is one of the largest players, especially for data networks and big data ${ }^{28}$.

This indicates that China may have good chances to emerge as a future producer of some of those technologies. It is unclear however whether China has the capacity to develop commercially successful Industry 4.0 application platforms. The Fraunhofer study highlights “...the relatively low innovative quality of Chinese utility model applications and patent submissions when it comes to the application of industry 4.0 technologies. Numerous lownovelty inventions have been registered, usually formulated in very imprecise terms.” For foreign companies, this certainly provides opportunities to penetrate the Chinese market by offering innovative advanced manufacturing solutions ${ }^{29}$.

Despite considerable implementation constraints, MIC 2025 is likely to produce substantial improvements in manufacturing productivity. A report from the US Manufacturers Alliance for Productivity and Innovation(MAPI) concludes: "The infrastructure of doing businesseducation, management, rule of law, and governance-would presumably improve, lowering operating costs and decreasing uncertainty. Western companies only stand to gain from any Chinese success." ${ }^{30}$ In short, MIC 2025 appears to be "much better conceived and more appropriate for China's situation than the "indigenous innovation" approach and SEIs .... [the Strategic Emerging Industries plan]. It will be more coordinated and utilize a wider array of policy tools. “31

\section{iii) But where are manufacturing employment data?}

Arguably one of the most problematic weaknesses of China's MIC 2025 plan is a failure to take into account employment effects. Interviews with China-based scholars and industry experts conveyed one over-riding message - Chinese policy makers have largely neglected employment

effects and other labor market issues when designing their grand visions of industrial policy ${ }^{32,33}$. This starts with very basic definitions. According to one observer, "to my own knowledge, there is no specific statistics on Chinese advanced manufacturing (AM) or on the employment effects of Chinese AM. Indeed, the Chinese government hasn't got a clear concept about AM (even though some policy-makers may think they have). Therefore, quite many companies reported their products as AM equipment, but the policy-makers haven't developed a clear criterion to 
define AM. ... if there is any report or statistics on this issue, my colleague and I do not think they are serious enough. "34

Here is what a well-informed Chinese source had to say:

"The Ministry of Industry and Information Technology (MIIT) has not developed any formal statistics for AM yet, and no research has been conducted on the effect of MIC2025 on employment. In fact, what MII emphasizes right now is still the "machinery" technologies, such as the smart manufacturing, $3 D$ print, robots, etc.

As for the ten priority sectors highlighted in the MIC 2025 plan, proponents have not raised the issue of employment. In fact, this document was compiled by technical experts, mostly from the Chinese Academy of Engineering. The ten priority sectors reflect ... the competition among different disciplines within the Chinese Academy of Engineering. Indeed, the ten priority sectors were not decided by any strategic policy-makers, but mainly by the community of researchers.... it was just a game of competing for policy money. ... those researchers care little about employment and skills.... In short, there is no formal policy discussion about skilled workers as part of the MIC 2025 plan. „35

A frequent explanation for the lack of robust employment projections is that at the top leadership level, engineers continue to dominate who "mostly do not understand the economy. .. [They are] used to the idea that the rural area of China is such a huge pool for the resource of low cost labor - the labor can come or disappear automatically depended on whether you need it."36

Furthermore, the concept of MIC2025 “is relatively new for China and the 'political talk' was developed only in the first quarter of 2015.According to another well-placed source from within the government, administrative inefficiencies and inter-agency rivalries may also play a role in explaining the scarcity of serious data on expected employment effects of MIC 2025 and related plans: "I don't think labor departments participated a lot in industry policy making in the past and present days. From the industry making department perspective, there is a lack of data and expertise on labor issues. "37

In short, there is no doubt that the MIC 2015 plan will place China on the map of serious contenders for the application of advanced manufacturing. However, a massive technology acquisition drive on its own will not automatically foster China's economic growth and prosperity. If overdone, Chinese factories would invest substantial amounts in factory automation, "but they may end up doing all of that just as inefficiently as their current manufacturing. Gross production may be huge, but it could be accompanied by a concurrent rise in Chinese corporate debt."38

Most problematic however is that Chinese policy makers have failed to base their design of the MIC 2025 on robust projections of possible employment effects and other labor market issues. After all, advanced manufacturing will produce sustainable economic and social benefits only, if this will produce a sufficiently large number of well-paid quality jobs, whether directly in manufacturing or in related industrial services. However, as we saw, the publicly available data provide no robust projections of future job creation in China. 
Part Three - What Do We Know about China's Manufacturing Employment Dynamics? Collecting data on China's manufacturing employment and qualitative examples was quite an adventure - the author had to conduct a considerable amount of detective work, given the imponderability of China's data on manufacturing employment, wages and quality of jobs. The only official statistics on employment is on the website of China's National Bureau of Statistics $(N B S)^{39}$, but the data are organized in such a way that it is quite tedious to construct proxy indicators for manufacturing employment. Interviews with China-based industry experts and researchers have helped me to navigate through this maze of fuzzy and sometimes conflicting information.

\section{i) Manufacturing as an employment absorber}

Before we get into the data, it is important to place the search for China's manufacturing employment data in a broader perspective. Debates in the US about the future of manufacturing employment in essence conclude that the decline in manufacturing employment results from the combined forces of technical change (through automation and robots) and globalization (through trade and FDI in global networks). According to the US Bureau of Labor Statistics (BLS), the share of jobs available in US manufacturing has been declining steadily since the mid-1950s. But after 2000, this share declined steeply, especially during the recessions of 2001-02 and 20082010. ${ }^{40}$

China however raises a puzzle: While China today is the largest global manufacturing site, manufacturing employment in China thus far does not follow the pattern observed for the US. The available manufacturing employment data show no sign that China has followed the "employment deindustrialization" observed in the US. Nor are there signs of a "premature deindustrialization.”

As Nick Lardy, a China expert at the Peterson Institute for International Economics, observes: "Manufacturing employment did dip by 18 million or almost a fifth between 1995 and 2000, a period when the then Premier Zhu Rongji pushed through a far-reaching reform that resulted in the closure of thousands of inefficient state-owned firms. ${ }^{41}$ But as the effect of this reform waned, manufacturing employment rose steadily, not only in absolute numbers but also as a share of total employment." 4243

Research conducted by Judith Banister for the US Bureau of Labor Statistics (BLS) shows that "China's manufacturing employment showed a continual increase over the 2002-2009 time period, rising from 85.9 million in 2002 to 99.0 million in 2009. As Chinese employment grew by about 15 percent over the 7-year period, manufacturing employment in other countries covered by BLS was stable or declined. China's 2009 manufacturing employment was much greater than manufacturing employment in any other country: for example, manufacturing employment in the United States in 2009 was about 14.2 million, was 10.8 million in Japan, and was about 7.8 million in Germany."44

From 2003 to 2014 China's National Bureau of Statistics (NBS) reports that total urban manufacturing employment has doubled and the share of the urban workforce employed in manufacturing rose from 15 to 20 percent. In addition, "there are a significant number of 
manufacturing workers in rural areas, not reflected in the data in the table. Workers in private firms and self-employed engaged in manufacturing in rural areas rose from 14.5 million in 2003 to 23.6 million in 2014." 45

The table below confirms that manufacturing in China still acts as an employment absorber. While the percentage share of manufacturing in GDP declined from 32.5\% in 2003 to $29.9 \%$ in 2013, the share of persons employed in manufacturing increased from $27.9 \%$ in 2005 to a recordbreaking 29\% in 2015. Manufacturing industry continues its dominant position. In 2013, only Korea has a higher percentage share of manufacturing in GDP than China. In terms of employment effects, China has by far the largest percentage share of persons employed in manufacturing ${ }^{46}$.

\begin{tabular}{|c|c|c|c|c|}
\hline \multicolumn{5}{|c|}{$\begin{array}{l}\text { Manufacturing as an Employment Absorber: China, } \\
\text { US, Germany, Japan, Korea }\end{array}$} \\
\hline $\begin{array}{l}\text { Indicatorl } \\
\text { year/country }\end{array}$ & $\begin{array}{l}\text { \%of } \mathrm{mfg} \\
\text { in GDP } \\
2003\end{array}$ & $\begin{array}{l}\text { \%of } \mathrm{mfg} \\
\text { in GDP, } \\
2013\end{array}$ & \begin{tabular}{|l|}
$\%$ of \\
persons \\
employed \\
in $\mathrm{mfg}$, \\
2005
\end{tabular} & \begin{tabular}{|l|}
$\%$ of \\
persons \\
employed \\
in \\
$\mathrm{mfg}, 2012$
\end{tabular} \\
\hline China & 32.5 & 29.9 & 27.9 & $\begin{array}{l}28.0(29 \% \\
\text { in } 2015)\end{array}$ \\
\hline US & 13.3 & 12.1 & 10.1 & 10.3 \\
\hline Germany & 22.1 & 22.2 & 20.0 & 19.8 \\
\hline Japan & 19.5 & 18.8 & 18.0 & 16.9 \\
\hline Korea & 26.7 & 31.1 & 16.9 & 16.6 \\
\hline
\end{tabular}

Until now, rapid externally generated growth in manufacturing seems to explain why labor productivity growth in China's manufacturing industry has been accompanied by employment growth. This would confirm Evsey D. Domar's observation that income-generating productivity growth is necessary for employment growth ${ }^{47}$.

To explain why employment growth in China thus far went hand in hand with productivity growth, it is worth quoting in some detail the analysis of Nick Lardy ${ }^{48}$ :

" "The rapid rise in both domestic and foreign demand for Chinese manufactures swamped significant productivity gains, leading to a sizable increase in the share of workers employed in Chinese manufacturing over the last 10 to 15 years.... China is growing at a pace several times that of the United States and it is at a much lower level of per capita income than the United States ... .As a result, Chinese household consumption patterns, while beginning to change, are much more concentrated on goods rather than services, leading to strong growth of manufacturing output. China's growth over the past decade and a half has been driven largely by a high and rising share of investment in GDP, further compounding the demand for inputs produced in the manufacturing sector. Finally, the liberalization of the economy associated with China's entry into the World Trade Organization (WTO) in 2001 led to a huge surge in China's 
share of global exports and particularly its share of global manufacturing exports, which tripled from 6 percent in 2000 to 18 percent in 2012. In contrast, over the same period the US share fell by half, from 18 to 9 percent. As a result ..., the pace of real growth of manufacturing output in China ... [between 2000 and 2012] ...was about eight times faster than in the United States.”

\section{ii) How will the shift to Advanced Manufacturing affect manufacturing employment? But what is happening now as China's growth is slowing and as the MIC 2025 plan seeks to forge ahead in advanced manufacturing? How might the disruptive shift to slower growth, combined with a massive move to advanced manufacturing reshuffle China's cards for job creation? In short, will the positive manufacturing employment effect be reversed?}

Any attempt to answer these questions is constrained by the lack of robust projections of the future of manufacturing jobs in China that was highlighted in Part Two of this paper.

The China Center for Information Industry Development (CCID) provides a few publicly available proxy indicators of employment trends in China's ICT industry. In this industry, the number of employees increased during China's $11^{\text {th }}$ Five-year Plan period (2006-2010), from 22.44 million to 32.94 million, with an annual growth rate of 10.1\%. For China's chip design industry, CCID reports that the total number of employees increased by almost 15\% in 2014 relative to 2013 to ca 147,000. As the average sales per employee increased by 13\% in 2014 to $\$ 116,000$, this arguably provides a very rough proxy for the sector's productivity growth ${ }^{49}$.

The China Labour Statistical Yearbook 2014 reports a decline of manufacturing employment from 543.4 million in 1994 to 298.1 million in 2002, but shows a quite significant increase from 298.0 million in 2003 to 525.8 million in 2013. And the China Statistics Yearbook of High Technology Industry 2013 reports that employment in both high-tech industries and manufacturing industry in general has increased from 2000 to 2012.Apart from these data crumbs, it was not possible to find useful manufacturing employment data in the public domain.

\section{iii) New data on unemployment - Is China now moving towards "employment deindustrialization"?}

An examination of unemployment data might in principle provide useful insights into the employment dynamics of China's manufacturing industry.

In China, the unemployment rate measures the number of people actively looking for a job as a percentage of the labor force, a measure that differs from those used in most OECD countries. China's official unemployment rate, as reported by the Ministry of Human Resources and Social Security, has remained practically constant since 2003 slightly below the $4.1 \%$ mark - a quite surrealistic "achievement" for an economy that has grown at lightning speed with drastic changes in its composition ${ }^{50}$. Collecting data on the real amount of manufacturing unemployment however is considered to be quite sensitive, almost as sensitive as research on labor conflicts.

A recent NBER working paper calculates, for the first time, China's unemployment rate from 1988 to 2009 using a more reliable, nationally representative household survey in China ${ }^{51}$. The 
paper documents to what degree the official statistics underestimate China's real unemployment rate (see Figure below). The unemployment rates calculated by the NBER study differ dramatically from those supplied in official data and are much more consistent with what is known about China's labor market and how it has changed over time in response to structural changes and other significant events. The NBER unemployment rate averaged 3.9\% in 19881995, when the labor market was highly regulated and dominated by state-owned enterprises, but rose sharply during the period of mass layoff from 1995- 2002, reaching an average of $10.9 \%$ in the period from 2002 to 2009. The study estimates that the actual unemployment rate in 2002-09 averaged nearly 11 percent, while the official rate averaged less than half that. Moreover, despite some reports to the contrary, by 2009 China's labor market had still not recovered from huge layoffs that occurred during the later 1990s and early 2000s as the nation transitioned from a government-controlled economy to one in which private enterprise and market forces were more at play $^{52}$.

Of particular interest for our purposes are the significantly different unemployment rates for different demographic groups, different regions, and different cohorts. The study finds that "people without college degrees, younger people, and females systematically face more slack labor markets than their more educated, older, and male counterparts...The most striking pattern is that younger people had very high unemployment rates, especially for more recent cohorts... Even at the age of around 30, the 1970s female cohorts had roughly a 10 percent unemployment rate, as compared to only 3 percent for females born in the 1960s."

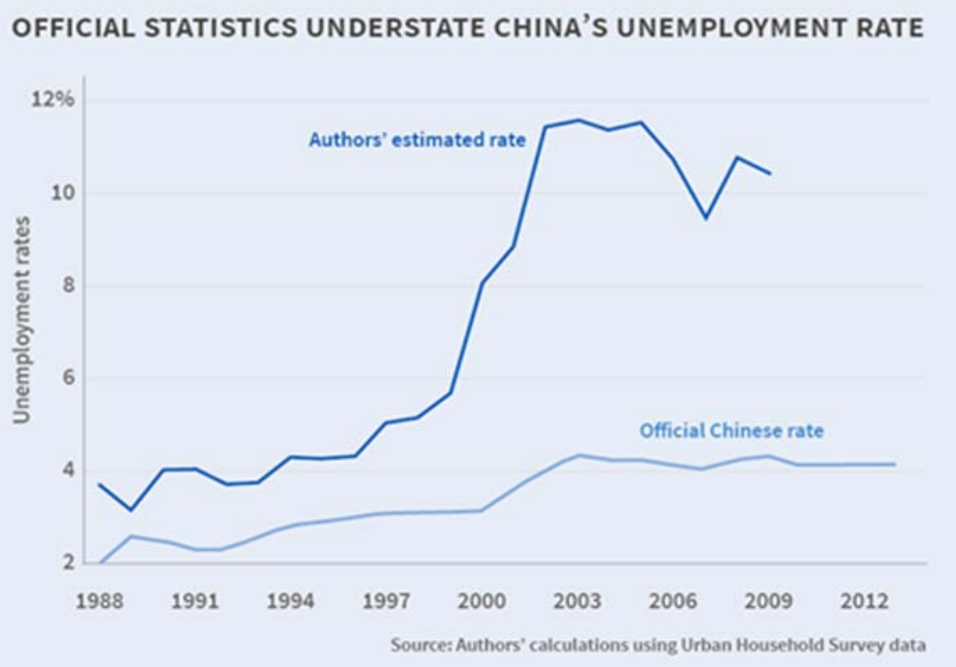

Long Run Trends in Unemployment and Labor Force Participation in China (NBER Working Paper No. 21450 it

The NBER paper also documents significant regional disparities in unemployment rates, as some regions fared worse than others. The Northeast, South Central, and Southwest regions of the country saw the largest increases in their unemployment rates during the 1995-2002 period. These were also the regions with the greatest number of layoffs by state-owned enterprises (SOEs). In the Northeast region, for example, some 7.3 million workers were laid off during the period - 42 percent of its total SOE employment in 1995. 
The NBER study finds that labor force participation rates (which are not available in official statistics) have declined throughout the whole period, particularly from 1995 to 2002 when the unemployment rate increased most significantly. While China's unemployment rate has soared since the mid-1990s, labor force participation has dropped. Participation averaged 83.1 percent around 1995, fell dramatically during the transition, and stabilized at around 74 percent during the 2002-09 period. Young people were hit especially hard by the layoffs during the 1995-2002 period. The labor force participation rate of young men and women, with and without college education, all fell by more than 10 percentage points.

The quite significant diversity in employment outcomes, reported in the NBER study, might well reflect the increasing inequality of income that China has been experiencing since the turn of the century. A recent study for the US National Academy of Sciences (NAS) finds a rapid increase in income inequality in China's recent past, drawing on newly available survey data collected by several Chinese university survey organizations (see figure below) ${ }^{53}$.

According to the NAS study, China's income inequality not only surpasses that of the United States by a large margin but also ranks among the highest in the world, especially in comparison with countries with comparable or higher standards of living. The study argues that China's current high income inequality is significantly driven by structural factors attributable to the Chinese political system, the main structural determinants being the rural-urban divide and the regional variation in economic well-being.

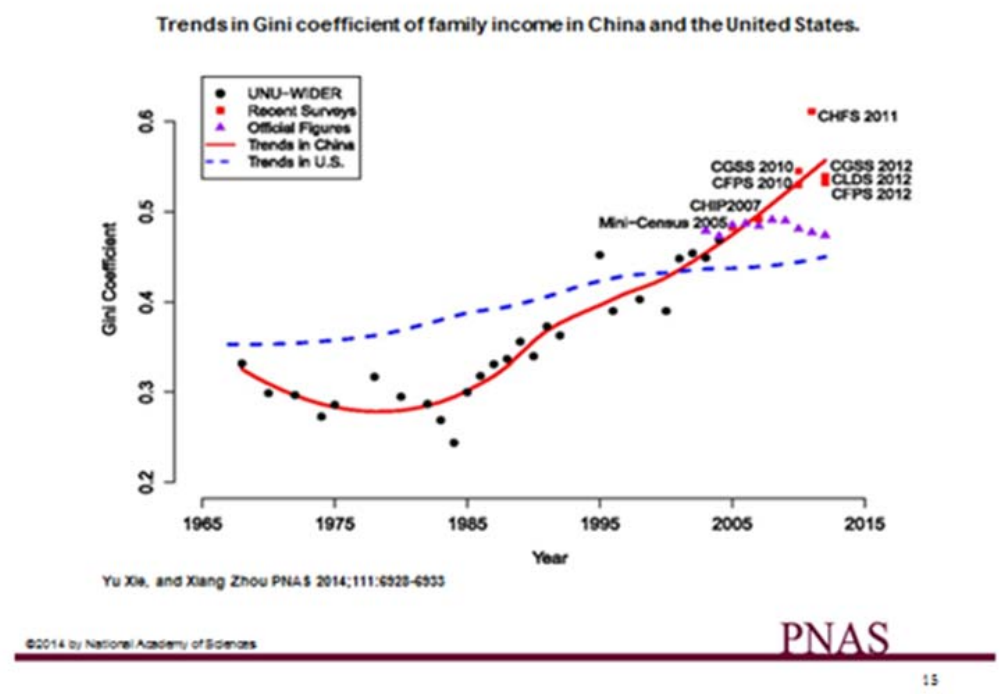

Of particular concern for China's "Future of Jobs" is the high unemployment rate among university graduates which apparently has been rising over the last years. The Chinese Academy of Social Sciences (CASS) reports a graduate unemployment rate of $12 \%$ in 2010, while foreign observers estimate the graduate unemployment may be as high as $27 \%{ }^{54} \mathrm{~A}$ recent study, jointly conducted by the Texas A\&M University and China's Southwestern University of Finance and Economics found that $16.4 \%$ of university graduates between the ages of 21 and 25 were unemployed, whereas only $4.2 \%$ of those in the same age bracket who have dropped out before 
middle school were unemployed. ${ }^{55}$ Despite high graduate unemployment however, US firms in China report a lack of availability of talent as a top-ranking operating challenge ${ }^{56}$.

\section{Implications for Policy and Further Research}

This Think Piece has explored possible employment effects of China's push into advanced manufacturing, focusing on the 10-year plan, issued by the State Council on May 19,2015, entitled "Made in China 2025 MIC2025" "中国制造2025". According to offical data, industrial manufacturing has played an important role as an employment absorber until around 2014.

However, we know very little about China's future of jobs now that China's growth is slowing and as the new push into advanced manufacturing gathers momentum. Furthermore, new data on unemployment, labor force participation, and income inequality raise the question whether China may now be moving towards an "employment de-industrialization" pattern. Alternatively, are enough knowledge-intensive service jobs being created in China's growing information economy, which after all is the necessary foundation for efforts to forge ahead in advanced manufacturing?

In short, we'd need to know whether knowledge-intensive manufacturing services might create a sufficient amount of quality spillover employment effects to support China's push into advanced manufacturing? And what kind of policies might be conducive for such indirect spillover employment effects?

Because of data limitations, the answer to those questions is left for further investigation in the future. The following observations and questions might help to lay out such a research agenda.

\section{Insights from research on manufacturing services}

Research in the US and other industrialized countries leaves little doubt that robots and other advanced manufacturing technologies are bound to reduce the DIRECT labor requirements of China's manufacturing industry. ${ }^{57}$ For the US, Pisano and Shih find:“" Manufacturing now accounts for only about one in ten American jobs. With increasing productivity,... it is hard to imagine how manufacturing could ever return to the days when it employed about a quarter of the US workforce."58

For the US, Susan Helper, the former chief economist of the Department of Commerce, argues that, for a firm to sustain productivity gains, it is necessary that it pays higher wages to its workers than competing firms ${ }^{59}$. These higher wages in turn have the potential to create a virtuous circle: better paid workers are more motivated to create productivity-enhancing product and process innovations; in turn, these productivity gains support higher wages. It is interesting to note that Bart van Ark, senior economist at the US Conference Board (a US-based Think tank for global business), supports the argument that higher wages may create income-generating productivity gains. $^{60}$

Recent research by the US Academy of Engineering has identified the proliferation of manufacturing services as an important source for quality jobs ${ }^{61}$. By integrating manufacturing, services and R\&D, successful firms can use advanced manufacturing technologies to provide 
packaged solutions that combine high productivity gains with substantial job gains in complementary support services.

The graph below illustrates the great variety of knowledge-intensive support services required for a fairly traditional type of PC manufacturing.

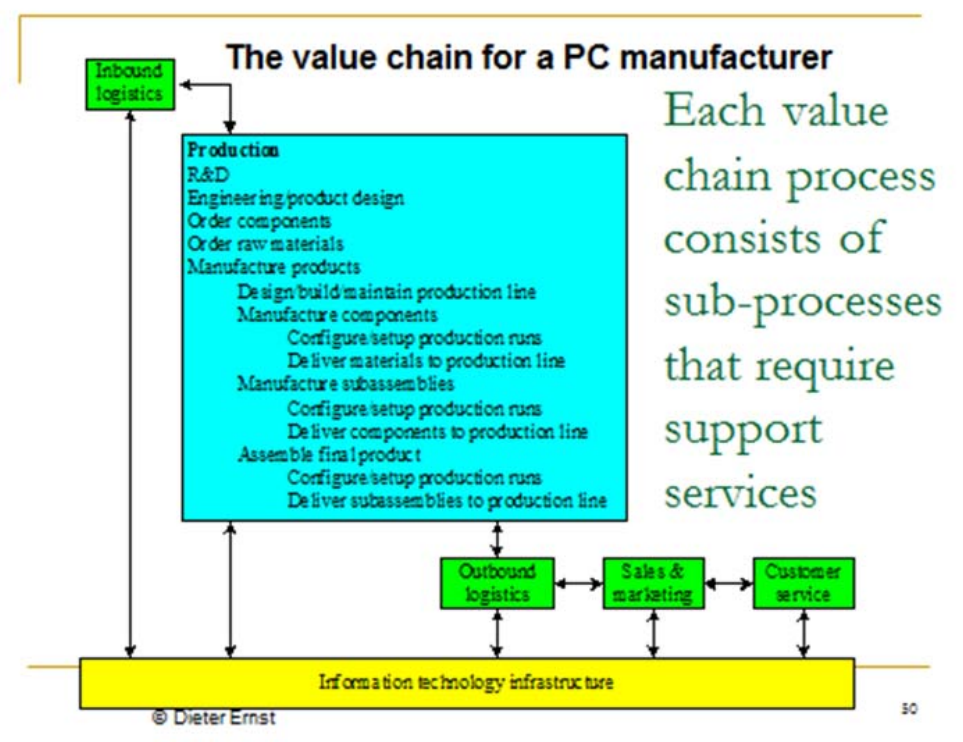

And a 2011 study by the UK-based Work Foundation finds that 70\% of UK manufacturing firms are offering the following manufacturing services that create quality jobs: Design \& product development (22\%); Systems \& solutions (19\%); Maintenance \& support (12\%); Retail \& distribution (12\%); and Installation \& implementation (5\%) ${ }^{62}$.

Another important source of quality service jobs necessary for advanced manufacturing can be found in a variety of digital infrastructure platforms ${ }^{63}$, such as broadband as an enabler of new applications (e.g., cloud computing); 4G wireless communications; integrated health information systems; smart electric grids; low carbon energy information systems; intelligent transportation systems; mobile payments systems; and mobile Collaborative Learning Systems ${ }^{64}$.

\section{Implications for policy-oriented research in China}

In order to assess whether China will be able to generate a sufficient amount of quality jobs, we need data on the growth of employment in knowledge-intensive services that are required to implement advanced manufacturing technologies. MIIT, through its "China Info 100" committee, provides the following data points on the development of China's innovation economy. Unfortunately, there is no definition provided of how China's information economy is measured $^{65}$.

Nevertheless as an indication of the self-perception of parts of the Chinese government, it is useful to quote these data. In 2014, China's information economy is reported to have reached Yuan 16.76 trillion (ca \$ 2.73 trillion), ranking as number two after the $\mathrm{US}^{66}$. While in 2008, the size of China's information economy expanded by almost $11 \%$, it grew by more than $14 \%$ in 2014. In 2014, the percentage share of China's information economy in GDP for the first time exceeded 25\%, and it is reported to have contributed more than 58\% to China's GDP growth. 
Assuming that these data indicate roughly the order of magnitude of growth in China's IT-related services, what then do we know about the growth of jobs in those services? Data from the National Bureau of Statistics (NBS) for instance show that the number of employees in telecommunications and other information services has increased by more than $74 \%$ over eight years from 812,511 in 2003 to 1,416,417 in 2011 (the latest year for which data are available), with employment growth accelerating since 2008. And for the number of workers in computer services and software, NBS reports a 76\% growth within three years from 1,858,000 in 2010 to $3,273,100$ workers in $2013^{67}$.

Until we will have more precise data, it is worthwhile considering the following observations from interviews that were conducted for this paper with China experts. There is a broad consensus that the emphasis placed by MIC2025 on the use of robots and network-based upgrading of the 10 priority sectors is going to boost demand for workers with highly specialized skills, especially in the afore-mentioned knowledge-intensive services related to mobile communications, software and chip design. But no data seem to be available in the public domain on the size of projected specialized skill requirements. This lack of reliable data constitutes an important handicap for China’s push into Advanced Manufacturing.

Quite a few interviewees emphasize that the scarcity of specialized skills needed for the big push in advanced manufacturing is an important factor in explaining the rise in graduate unemployment described before. Interviewees also report that growing demand for IT-related specialized skills is driving up wages for those skilled workers. This demand boost for highly specialized skills seems to crowd out smaller domestic firms, and leave the field to a few large companies, whether foreign MNCs or large Chinese corporations like Huawei.

For example, one interviewee reports that the entry level pay for IC design engineers are higher today in Shanghai or Shenzhen than in Taipei. It is somewhat perplexing that despite such higher pay levels, leading Chinese IC design houses which are based in Shenzhen or Shanghai (like HiSilicon or Spreadtrum) are competing successfully with Taiwanese counterparts. One plausible explanation may be access to subsidies ${ }^{68}$. Another explanation may be the use of foreign (Taiwanese, US, Korean) engineers who are moonlighting in China (sometimes over the weekends). These foreign chip designers are used to work under best-practice R\&D management processes, and thus may well be more productive.

\section{Specific questions for further research}

1. How important is the Internet Plus (IP), a plan initiated by the State Council, China's cabinet? According to some interviewees, the IP Plan is supposed to complement MIC 2025. It strives to meld on a large scale the modern internet (cloud, mobile, and big data) with manufacturing and electronic retail trade. Few details are available, although an action plan is supposed to be forthcoming. The plan will likely focus on upgrading traditional industries with modern technology, and will search for new technologies to spur economic growth, and spreading internet applications. Research is needed to identify precise objectives and implementation policies. 
2. It might help to connect China's evolving domestic consumption patterns with China's "Future of Jobs" puzzle. As the Chinese economic model moves from exports to domestic consumption, Chinese consumers might demand more advanced goods and services. How might this affect employment in advanced manufacturing?

For example, the rise of Chinese consumers in the information communications and technology market has enabled Chinese technology firms (such as Huawei, ZTE, Xiaomi, and Oppo, as well as chip design companies like Spreadtrum) to compete at the lower-end domestic market and then move up in value as the domestic market demands more sophisticated goods. Because of China's rising middle class and their new consumption power, domestic firms are poised to have more opportunities to create what Clayton Christensen is calling "market-creating" innovations (innovations that expand the labor market).$^{69}$ So perhaps China can avoid negative spillover effects because domestic consumption of advanced goods can sufficiently offset the job losses of using less labor intensive manufacturing methods?

3. In addition, we'd need research that would examine data for instance on the following questions:

i) Might the growth of advanced manufacturing (AM) employment in traditional activities that create products which face growing demand be able to compensate for the displacement of traditional manufacturing jobs?

This question actually relates to an old debate among economists about the conditions under which the introduction of labor-displacing technology might create more jobs than are displaced. Take David Ricardo who, in the 1817 edition of The Principles of Political Economy and Taxation, argued that over the long run, growing demand should compensate for temporary job losses. But in a revised edition in 1822, he reversed his original position, arguing that mechanization would prove "often very injurious" to workers ${ }^{70}$. Or take John Maynard Keynes who, more than 100 years later observed: "We are being afflicted with a new disease, namely technological unemployment. This means unemployment due to our discovery of means of economising the use of labour outrunning the pace at which we can find new uses for labour.,"71

ii) We need in-depth research on the growth of employment in software and other services to support the growth of advanced manufacturing and the resultant requirements for skill upgrading.

iii) We'd also need research on the growth of employment in the production of advanced manufacturing equipment (such as autonomous robots, computing and communication equipment for Big Data centers, etc) as an upstream activity to the use of advanced manufacturing technologies .

iv) Furthermore, important insights on the potentially huge indirect employment effects of advanced manufacturing could be gained from the study of China's massive investments in digital infrastructure platforms, in particular China's Smart Grid project ${ }^{72}$. 
v) Finally, we'd need research on new manufacturing activities that are enabled by advanced manufacturing technologies that did not exist before (by industry or level in the value chain). Is it correct to assume that some of these new manufacturing activities (like the growth of generic drug manufacturing or solar panel manufacturing) may not displace jobs in traditional manufacturing activities?

\footnotetext{
${ }^{1}$ This paper was prepared for the conference at Mount Holyoke on February 19-20th: " The Future of Jobs: The Dual Challenges of Globalization and Robotization, Febr 19-20, 2016." I am grateful for comments and suggestions received from CHEN Ling, School of Public Policy \& Management Tsinghua University, Beijing; CHEN Tain-Jy, National Taiwan University, Taipei; FENG Kaidong, School of Government, Peking University, Beijing; Bob Fonow, RGI Ltd., 北京茂瑞咨询有限公司, Beijing; Ambassador Chas W. Freeman Jr., Projects International, Inc; Ellen Frost, East-West Center Washington D.C. Office; Seamus Grimes, Whitaker Institute, National University of Ireland, Galway; Scott Kennedy, Freeman Chair in China Studies, Center for Strategic and International Studies, Washington, D.C.; Dan Kim, US International Trade Commission (USITC), Washington, D.C.; Bill Lazonick, University of Massachusetts at Lowell and The Academic-Industry Research Network; Keith E. Maskus, University of Colorado, Boulder; Eva Paus, McCulloch Center for Global Initiatives, Mount Holyoke College, South Hadley, MA; SUN Yutao, Faculty of Management and Economics, Dalian University of Technology and Marie Curie Research Fellow, School of Contemporary Chinese Studies, The University of Nottingham; WANG Ping, China National Institute for Standardization (CNIS), Beijing; XUE Lan, Dean, School of Public Policy and Management, Tsinghua University, Beijing; and Klaus Ziegler, DIN German Institute for Standardization, Beijing Office.

${ }^{2}$ Current debates on "Advanced Manufacturing" technologies emphasize their role as enablers of new products and services that might create new markets and industries. Mass customization, for instance through Additive Manufacturing (3D Printing) and autonomous robots, might enable Continuous Manufacturing in smaller, agile and flexible production facilities, closer to end-users. In turn, integrated solutions through bundling of physical products with services and software might enhance productivity and flexibility in large-scale manufacturing and supply and distribution chains (for instance through RFID tracking and Human-Robot-interaction). Furthermore, Advanced Manufacturing technologies are expected to enhance coordination and flexibility in global production and innovation networks. (See for instance, President's Advisers on Science and Technology (PCAST), 2014, Accelerating US Advanced Manufacturing, Washington, D.C, October; or Deutsche Bank Research, 2014, Industry 4.0. Upgrading of Germany's industrial capabilities on the horizon, April 23.)

${ }^{3}$ See the MIC2025 website http://english.cntv.cn/special/madeinchina/index.shtml. For an unofficial translation of the MIC2025 plan, see http://www.usito.org/content/usito-made-china-2025-unofficial-translation-2015-5-29. ${ }^{4}$ See, for instance Cai, Fang, 2013, "Approaching a neoclassical scenario: the labor market in China after the Lewis turning point”, China Finance and Economic Review, Vol.1, \#1: 8 pages. The author is the Director of the Institute of Population and Labor Economics at the Chinese Academy of Social Sciences and advises the government. He also serves as a Member of the Standing Committee and Agricultural and Rural Committee of the National People's Congress of China. There is still some debate about the precise timing of this shift to labor shortage. A 2013 working paper by the International Monetary Fund for instance expects the Lewis turning point in China to "emerge between 2020 and 2025." Das, Mitali; N'Diaye, Papa M. (2013). "Chronicle of a Decline Foretold: Has China Reached the Lewis Turning Point?", IMF Working Paper No. 13/26.

${ }^{5}$ Wildau, G., 2015, “China Migration at the turning point”, FT, May 4.

${ }^{6}$ The Conference Board, 2015, Productivity Brief 2015, May: p.16, https://www.conferenceboard.org/retrievefile.cfm?filename=The-Conference-Board-2015-Productivity-Brief.pdf\&type=subsite ${ }^{7}$ Lawrence, R. and L. Edwards, 2013, "US Employment Deindustrialization: Insights from History and the International Experience”, Policy Brief \# PB 13-27, Peterson Institute for International Economics, Washington, D.C., October: p.5.
} 
${ }^{8}$ As explained below, one might be skeptical about Martin Ford's statement that, as China expands the use of industrial robots, "Chinese factory jobs may thus be poised to evaporate at an even faster pace than has been the case in the United States and other developed countries. ... China could well turn out to be ground zero for the economic and social disruption brought on by the rise of the robots. "Ford, M., 2015, "China's troubling robot revolution", NYT, June 10.

${ }^{9}$ See for instance Yu Zhou, W. Lazonick, Sun Yifei, eds., 2016, China as an Innovation Nation, Oxford University Press, Oxford, New York; Ernst, D., 2015, From Catching Up to Forging Ahead: China's Policies for Semiconductors, East-West Center Special Study, September; and Ernst, D., 2011, Indigenous Innovation and Globalization: The Challenge for China's Standardization Strategy, UC Institute on Global Conflict and Cooperation; La Jolla, CA and East-West Center, Honolulu, HI., 123 pages [Published in Chinese at the University of International Business and Economics Press in Beijing, 自主创新与全球化：中国标准化战略所面临的挑战]. On the broader issues of China's development model, see Naughton, B. and K.S. Tsai, 2015, editors, State Capitalism, Institutional Adaptation, and the Chinese Miracle, Cambridge University Press.

${ }^{10}$ Rodrik, D., 2015, Premature Deindustrialization, Economics Working Paper 107, School of Social Science, Institute for Advanced Study, Princeton University, January: p3.

${ }^{11}$ For the science and technology plan, see State Council, "China's Medium- and Long-Term Plan for Science and Technology Development (2005-2020),” February 9, 2006, http://www.gov.cn/english/2006-

02/09/content 184426.htm. On the SEI plan, see 国务院关于印发“十二五”国家战略性新兴产业发展规划的通知 ["The State Council Notification on the Long-term Development Plan for Strategic Emerging Industries during the $12^{\text {th }}$ Five Year Plan”], 国发 [2012] 28号, July 7, 2012.

${ }^{12}$ Germany Trade \& Investment, 2015, Industrie 4.0. Smart manufacturing for the Future, http://www.gtai.de/GTAI/Content/EN/Invest/_SharedDocs/Downloads/GTAI/Brochures/Industries/industrie4.0smart-manufacturing-for-the-future-en.pdf

${ }^{13}$ The plan is also influenced by the advanced manufacturing initiatives in the European Commission (the European Factories of the Future program), and in France (Usine de Futur), the UK (High Value Manufacturing Catapult), the US (Advanced Manufacturing Partnership) , Japan (2014 White Paper on Industry), and Korea (Innovation in Industry 4.0), Taiwan (2014 Industrial Development Plan) and Singapore (iN2015 Masterplan). For instance, in line with the US Advanced Manufacturing Partnership (AMP 2.0) strategy, MIC 2025 seeks to promote innovation through a network of manufacturing innovation centers (15 by 2020, and 40 by 2025).

${ }^{14}$ Efforts to foster close cooperation with Germany's Industrie 4.0 initiative include the China-Germany Standardization Cooperation Commission, the China-Germany "Industry 4.0 dialogue", the "German-Chinese Alliance for Vocational Training and Education" and the joint framework for action plan called "Design innovation together!" For instance, the newly created China Academy of Industry 4.0 has published the "German Industry 4.0 Research Report" (distributed free of charge).

${ }^{15}$ Wuebekke, J. and B. Conrad, 2015, Industrie 4.0: Will German Technology Help China Catch up with the West?, China Monitor, Issue 23, 14 April: p.1.

${ }^{16}$ Deutsche Bank Research, 2015, Industry 4.0: China seizes an outstanding opportunity in the "Year of Innovation”, June 18.

${ }^{17}$ http://www.miit.gov.cn/

${ }^{18}$ USITO, Guidelines to Promote National Integrated Circuit Industry Development (unauthorized translation of document published by the Ministry of Industry and Information Technology, the National Development and Reform Commission, the Ministry of Finance, and the Department of Science and Technology), United States Information Technology Office, Beijing, June 24, 2014.

${ }^{19}$ For a detailed analysis of China's New Policies for Semiconductors, see Ernst, D., 2015, From Catching Up to Forging Ahead: China's Policies for Semiconductors, East-West Center Special Study, September.

${ }^{20}$ Shao Yongyu, 2015, Strategic vision and outlook of "Made in China 2025 (Part 2)" Mizuho China Monthly, September.

${ }^{21}$ http://www.ifr.org/news/ifr-press-release/statements-of-ceos-on-the-results-of-world-robotics-2015-774/ These data are provided by the Chinese Robot Alliance (CRIA), an important stakeholder in China's MIC 2025 plan. Established in April 2013, CRIA is a member of the International Federation of Robotics (IFR). CRIA now has more than 100 members from industry, universities, research institutes, regional or local robotic associations, as well as government-sponsored organizations in the fields of R\&D, manufacturing, application and services of the robot industry in China. CRIA's mission is to implement the government's industrial policies, to strengthen the exchanges 
and cooperation regarding technology, market and intellectual property rights among members, and international cooperation.

${ }^{22}$ A total of 1,000 robots are to be introduced at the factory initially, run by Shenzhen Evenwin Precision

Technology Co, with the aim of reducing the current workforce of 1,800 by 90 per cent to only about 200. Interview with Chen Xingqi, the chairman of Shenzhen Evenwin Precision Technology,

http://www.scmp.com/tech/enterprises/article/1786484/building-work-starts-first-all-robot-manufacturing-plantchinas?page $=$ all.

${ }^{23}$ The South China Morning Post reports that since September 2014, "a total of 505 factories across Dongguan have invested 4.2 billion yuan (USD 644,574,000.00)in robots, aiming to replace more than 30,000 workers, according to the Dongguan Economy and Information Technology Bureau. ...The provincial capital, Guangzhou, has set a goal of fostering a robot-manufacturing industry with an output value of more than 100 billion yuan (USD

$15,347,000,000.00$ ) by 2020 , as well as automating more than 80 per cent of the city's manufacturing production. http://www.scmp.com/lifestyle/technology/science-research/article/1754165/robotics-industry-booming-guangdonginsiders

${ }^{24}$ Wuebekke, J. and B. Conrad, 2015, Industrie 4.0: Will German Technology Help China Catch up with the West?, China Monitor, Issue 23, 14 April: 10 pages.

${ }^{25} \mathrm{http}: / / \mathrm{www}$. shsiasun.com/en/ . Founded in the year 2000, the company has a market capitalization of $\$ 13.3$ billion (as of June 2015), 2,4480 employees, and sales of \$247 mn.

${ }^{26}$ http://www.ifr.org/industrial-robots/statistics/

${ }^{27}$ Fraunhofer has analyzed 1700 patent documents published in China between January 2013 and April 2015 for industry 4.0 technologies. Technology experts identified the 50 most important inventions, translated the documentation, compiled it by hand and evaluated it accordingly. http://www.iao.fraunhofer.de/lang-en/technologyinnovation-management/iao-news/1230-top-50-chinese-industry-4-0-patents.html

${ }^{28}$ The Fraunhofer study shows that, for instance for wireless sensor networks, Chinese inventors have registered important basic patents over the past three years for energy-efficient technologies intended for industrial use.

Leading institutions such as the Shenyang Institute of Automation (SIA) developed and patented new approaches for operating energy-efficient and reliable industrial networks. In robotics, China's largest robot manufacturer, SIASUN, has registered around 140 inventions a year for the past three years - and there are 300 or so other Chinese robot manufacturers active in the market as well. Big data is another area in which China ranks among the key patent applicants, with internet giants such as Alibaba, Tencent and Baidu being joined by less well-known companies in registering important patents for big data processing methods as well as ways to improve data security, for example using quantum encryption.

${ }^{29}$ Fraunhofer emphasizes the flipside of China's low quality of AM patents: This may well open up opportunities for Chinese non-performing entities ("patent trolls") - "Chinese inventors are protected by a variety of trivial, yet effective, intellectual property rights, so any company wanting to penetrate the Chinese market must expect to encounter quite a few legal disputes along the way.” (ibid)

${ }^{30}$ https://www.mapi.net/forecasts-data/internet-things-industrie-40-vs-industrial-internet\#1

${ }^{31}$ Interview with Scott Kennedy of the Center for Strategic and International Studies, "Made in China 2025”, http://csis.org/publication/made-china-2025. Kennedy emphasizes that "the term 'indigenous innovation' appears only twice and "SEI" only once. There is no obvious effort to paint this as the successor to or extension of SEI, but in fact, to show that an SEI-oriented focus was too narrow and built on a misunderstanding of China's core needs and comparative advantage.”

${ }^{32}$ Due to the sensitivity of this topic, all interview partners have requested anonymity.

${ }^{33}$ An exception may be the association "China Info 100" (http://www.chinainfo100.com/) ) under the MIIT, which was created around 2005 as the "China's Expert Committee of Informationalization" by the State Council as a negotiation and coordination mechanism across different ministries, firms and academia.

${ }^{34}$ Email to the author, dated January 25, 2016, from source A, who requests anonymity.

${ }^{35}$ Email to the author, dated February 1, 2016, from source B who requests anonymity.

${ }^{36}$ Email to the author, dated February 9, 2016, from source $C$ who requests anonymity.

${ }^{37}$ Email to the author, dated February 7, 2016, from source D who requests anonymity.

${ }^{38}$ Email to the author, dated February 8, 2016, from Scott Kennedy, deputy director of the Freeman Chair in China Studies, Center for Strategic and International Studies.

${ }^{39} \mathrm{http}: / /$ data.stats.gov.cn/english/easyquery.htm?cn=C01

${ }^{40}$ http://www.bls.gov/web/empsit/ceshighlights.pdf

${ }^{41}$ Quoting data from the Chinese Statistical Yearbook 2009, p. 116. 
${ }^{42}$ Lardy, N.R., Manufacturing Employment in China, China Economic Watch, PIIE, http://blogs.piie.com/china/?p=4593

${ }^{43}$ Martin Ford's argument that automation was the main culprit behind the massive decline of Chinese factory jobs, does not match with available evidence. Ford quotes the massive loss of 16 million factory jobs between 1995 and 2002. However, placing the blame on automation and robots neglects that the aggressive reform of the state-owned enterprise (SOE) sector was the primary cause for this massive decline in China's industrial jobs (roughly $15 \%$ of China’s 1995 manufacturing employment).

${ }^{44}$ Banister, J., 2013, “China’s manufacturing employment and hourly labor compensation, 2002-2009”, International Labor Comparisons (ILC), June 7, http://www.bls.gov/fls/china_method.pdf . Unfortunately, U.S. Congress discontinued funding for the BLS-ILC, thus closing down this extremely useful data source,.

${ }^{45}$ Lardy, N.R., Manufacturing Employment in China, China Economic Watch, PIIE, http://blogs.piie.com/china/?p=4593

${ }^{46}$ See Shao Yongyu, 2015, "Strategic vision and outlook of Made in China 2025 (Part 1)", Mizuho China Monthly, July; and Part 2, September.

${ }^{47}$ Domar's important insight seems to have been largely forgotten: "Employment is ... dependent on national income, and national income has something to do with investment. .. [F]or an individual firm, investment may mean more capital and less labor... [B] ut for the economy as a whole ...if both ... [capital and labor]... are to be profitably employed, a growth of income must take place." (Domar, E.D., 1946, "Capital Expansion, Rate of Growth, and Employment”, Econometrica, Vol. 14, No. 2, April: pp. 137-147). In other words, productivity growth that leads to cost reduction alone is insufficient. Innovation needs to increase as well the value of output through improvements in product performance.

${ }^{48}$ Lardy, N.R., Manufacturing Employment in China, China Economic Watch, Peterson Institute for International Economics (PIIE), http://blogs.piie.com/china/?p=4593

${ }^{49}$ CCID figures are quoted in https://www.pwc.com/gx/en/technology/pdf/china-semicon-2015-report1-3.pdf :p.14

${ }^{50}$ According to the Ministry of Human Resources and Social Security of the PRC, the unemployment rate in China remained unchanged at 4.05 percent in the fourth quarter of 2015 from 4.05 percent in the third quarter of 2015. The reported unemployment rate in China averaged 4.13 percent from 2002 until 2015, reaching an all-time high of 4.30 percent in the fourth quarter of 2003 and a record low of 3.90 percent in the third quarter of 2002. These official unemployment data are clearly unrealistic, given the dramatic speed of change in China's manufacturing industry.

${ }^{51}$ Shuaizhang Feng, Yingyao Hu, Robert Moffitt, 2015, "Long Run Trends in Unemployment and Labor Force Participation in China” NBER Working Paper No. 21460, August; 44 pages, http://www.nber.org/papers/w21460 The paper argues:” The official unemployment rate series for China is implausible and is an outlier in the distribution of unemployment rates across countries ranked by their stage of development. There is strong evidence that this is the result of mismeasurement of the official rate.” (ibid.:p.23)

${ }^{52}$ Quoted from http://www.nber.org/digest/oct15/w21460.html

${ }^{53} \mathrm{Yu}$ Xie and Xiang Zhou, Income inequality in today's China, Proceedings of the U.S. National Academy of Sciences, vol. 111 no. 19: pages 6928-6933. Gini coefficients from UNU-WIDER and CHIP 2007 are based on household disposable income per capita. Gini coefficients of family income in the United States from 1967 to 2012 are provided by the US Census Bureau. A Gini coefficient measures the income distribution of a country's residents. This number, which ranges between 0 and 1 and is based on residents' net income, helps define the gap between the rich and the poor, with 0 representing perfect equality and 1 representing perfect inequality.

${ }^{54} \mathrm{http}: / / k n o w l e d g e . c k g s b . e d u . c n / 2014 / 07 / 21 /$ employment/unemployment-in-china-degree-to-nowhere/

55 China's Household Finance Survey 2014, quoted in Xin En Lee, 2014, "Unemployment in China: Degree to Nowhere”, CKGSB Knowledge, July 21, http://knowledge.ckgsb.edu.cn/2014/07/21/employment/unemployment-inchina-degree-to-nowhere/

${ }^{56} \mathrm{http}: / /$ www.amcham-shanghai.org/NR/rdonlyres/CEF3B375-976F-4EED-A306A44FFAAA4378/13851/mar11_cover_story.pdf

${ }^{57}$ Shipp, S.S. et al, 2012, Report on Emerging Global Trends in Advanced Manufacturing, Institute for Defense Analyses- Science Technology Policy Institute (IDA-STPI), Washington, D.C.

${ }^{58}$ Pisano, G. and W. Shih, 2012, Producing Prosperity. Why America Needs a Manufacturing Renaissance, Harvard Business School Press

${ }^{59}$ Helper, S., T. Krueger, H. Wial, 2012, Why Does Manufacturing Matter? Which Manufacturing Matters? Brookings Institution, Washington, D.C.

${ }^{60}$ According to van Ark, paying good wages is "a very sensible economic growth model," because workers then invest in training and education, which drive up returns for their employers, and buy products and services, which 
helps sustain the consumer economy.....When workers receive lower wages than they deserve, they do not develop their skills or work as hard, which pushes down corporate revenues."

http://www.conference-board.org/data/datadetail.cfm?dataid=straighttalk

${ }^{61}$ National Academy of Engineering, 2012, Making Value: Integrating Manufacturing, Design and Innovation, The national Academies Press, Washington, D.C.

${ }^{62}$ Sissons, A., 2011, More than making things. A new future for manufacturing in a service economy, The Work Foundation, Lancaster University, March: fig.2.1, p.23.

${ }^{63}$ McDonald, M.P., 2013, Platforms Are the New Foundation of Corporate IT, HBR, August 1.

${ }^{64}$ See also Atkinson, R. and S. Ezell, 2012, Innovation Economics. The Race for Global Advantage, Yale University Press; pages 257 and 258.

${ }^{65}$ For the OECD approach to measuring the Information Economy, see http://www.oecd.org/economy/oecd-digitaleconomy-outlook-2015-9789264232440-en.htm

${ }^{66} \mathrm{http}: / /$ www.chinainfo100.com/

${ }^{67}$ National Bureau of Statistics, 2015, data file Employment and output of telecom, computer services and software.

${ }^{68}$ According to some interviewees, Chinese policy-makers seem to understand now better that subsidies are not the best way to create competitive high-tech firms. Quite a few highly subsidized local firms in the Chinese TD-

SCDMA alliance have not been successful.

${ }_{70}^{69}$ https://hbr.org/2014/06/the-capitalists-dilemma

${ }^{70} \mathrm{http://www.econlib.org/library/Ricardo/ricP.html}$

${ }^{71}$ Keynes, J.M., 1930, Economic Possibilities for our Grandchildren, http://www.econ.yale.edu/smith/econ116a/keynes1.pdf

${ }^{72}$ Bloomberg News, 2015, “China Eyes Safe Smart-Grid System by 2020 to Push Clean Energy”, July 6 